\title{
Veterinary Science: A Model Discipline for Enhancing Diversity in the Sciences
}

\author{
Gillian Bowser ${ }^{1,2}$, Emily N. Quick Bear ${ }^{3}$, Amanda L. Purnell ${ }^{4}$ and Mark A. Brown ${ }^{2,4,5,6} *$
}

${ }^{1}$ Natural Resource Ecology Laboratory, Colorado State University, Fort Collins, CO, USA

${ }^{2}$ Alliance for Graduate Education and the Professoriate, Colorado State University, Fort Collins, CO, USA

${ }^{3}$ Department of Biology, Colorado State University, Fort Collins, CO, USA

${ }^{4}$ Institute for Learning and Teaching, Colorado State University, Fort Collins, CO, USA

${ }^{5}$ Department of Ethnic Studies, Colorado State University, Fort Collins, CO, USA

${ }^{6}$ Flint Animal Cancer Center, Department of Clinical Sciences, Fort Collins, CO, USA

*Corresponding author: Mark A. Brown, Flint Animal Cancer Center, Department of Clinical Sciences, Colorado State University, Campus 1052, Fort Collins, CO 80523-1052, USA, Phone: (970) 491-5782; Fax: (970) 491-3483; E-mail: M.Brown@colostate.edu

Copyright (C) 2012 Mark A. Brown et al. This is an open access article distributed under the Creative Commons Attribution License, which permits unrestricted use, distribution, and reproduction in any medium, provided the original work is properly cited.

\section{Abstract}

Following decades of being underrepresented in veterinary science and medicine, women now comprise over $70 \%$ of graduating veterinary students. Although the ethnic diversity of veterinary programs in the U.S. lags far behind that of the general population, it is well ahead of other science disciplines. More importantly, the American Veterinary Medical Association has identified ethnic diversity as an essential element of the health and sustainability of the veterinary profession. Following their initiative, almost every veterinary program in the country now boasts a robust diversity program to enhance the recruitment, retention, and career placement of ethnically diverse students. Given the failure of most science disciplines to make significant strides toward diversification; veterinary science stands out as a model discipline for enhancing diversity in the sciences. 
The number of African American, Alaskan Native, American Indian, and Hispanic students who complete programs in the sciences and seek employment in science careers is unacceptably low, as are the retention rates of the small number of underrepresented minority (URM) students who actually matriculate into science graduate and professional programs. Data indicate that while approximately 24,861 doctorates were awarded in the sciences by universities in the U.S. in 2005, students enrolled as underrepresented minorities earned only 1,034 or $4.2 \%$ of those degrees [1]. Such small numbers of URM students in these areas have a variety of negative impacts on issues that range from the U.S. economy and the conceptualization of graduate/professional degrees to educational outcomes that URM students consider as realistic options. It is widely acknowledged that diverse mentors/role models are critical to successful recruitment and retention programs [2]. If URM faculty members are a rarity in the sciences, how are URM graduate and professional students to find role models? Likewise, if underrepresented minorities are a rarity among the ranks of science professionals, how are recent URM graduates to find role models in science careers [3]? In order to move traditionally underrepresented students into graduate/professional programs and, ultimately, senior positions in science disciplines, we must first have a pipeline of programs that support URM student participation in undergraduate science education [4-6]. This includes: 1) developing relationships with prospective URM science students and their communities; 2) recruitment of URM high school graduates into undergraduate science programs; 3) recruitment of URM community college students into four-year science programs; 4) supporting rich undergraduate experiences that encourage real scientific practice and discourse coupled with student engagement in a community that respects, welcomes, and promotes diversity; 5) creating opportunities for students to be involved in the growth of their educational communities through mentoring, research, service and outreach; and 6) recruitment of those students into science graduate/professional programs and/or careers with a cohort of peers. Clearly, major changes must be made in the way students are recruited, retained and mentored throughout our educational system.

Most universities report dismal retention rates among URM students. So why do students leave the academy? Research on individuals enrolled in science programs consistently report that students who leave do not feel connected to others, their peers or their instructors [710]. They do not feel welcomed or engaged in their living environments or their classrooms. Often, these students do not feel confident in their ability to traverse the complex and sometimes frustrating system of their home department or institution $[11,12]$.

To circumvent these issues, most veterinary programs have developed robust diversity initiatives designed to address such obstacles based on a platform of student and faculty engagement. Indeed, it is clear that the entire veterinary profession has made a concerted effort to create a welcome and engaging atmosphere. It is no coincidence that this effort has been largely driven from the top by the American Veterinary Medical Association (AVMA) and the Association of American Veterinary Medical Colleges (AAVMC) [13]. In the last few decades, there has been a complete overhaul of the veterinary discipline which is steeped in tradition. While the most valuable and celebrated traditions remain, gone are the days of sex-based bias. For a profession once dominated by men, the fact that over $70 \%$ of graduating veterinary students and over $80 \%$ of entering veterinary students are women is a clear indication that the days of sexual bias in that profession are waning [14-16]. Just as telling is the fact that ethnic diversity has been on a sharp, upward trajectory in a discipline considered to be largely 
conservative. While only about $4 \%$ of students earning doctorates in the sciences in 2005 were URM, about $12 \%$ of graduating veterinary students are URM $[1,15,16]$.Since about a third of the U.S. population is comprised of underrepresented minorities, even the veterinary sciences have a long way to go in the way of diversification. However, the veterinary discipline has clearly outpaced other science disciplines. In fact, since the initiation of the DiVersity Matters Initiative by the AAVMC less than a decade ago, the matriculation of URM students in U.S. veterinary programs has improved by over $43 \%$ [13].

The authors here, along with colleagues in other science disciplines, are starting to put the lessons learned in veterinary sciences as they relate to diversity in all of the sciences to good use. Borrowing from the best diversity practices of veterinary programs, we have received funding from the National Science Foundation to develop diversity programs with broader impacts across the disciplines of science, technology, engineering, and mathematics (STEM). These include programs such as the Rocky Mountain Sustainability and Science Network (RMSSN), the Global Women Scholars Network (GWSN) and the Rocky Mountain Scholars Program (RMSP). In keeping with best practices in the discipline of veterinary science, the model of engagement we have adapted for our NSF diversity programs is Tinto's Model of Student Retention $[17,18]$. We have used this model to: 1 ) integrate, synergize, and institutionalize both new and ongoing STEM initiatives to support seamless student recruitment, retention, and graduation from STEM programs; 2) support incoming students with a stable community that respects, welcomes, and promotes diversity; 3) enrich the laboratory learning experience to actively engage undergraduate students and enhance their educational experience; 4) encourage students to explore opportunities in the sciences through research experiences outside the classroom; 5) support undergraduate students as they prepare to transition to graduate programs and/or careers in STEM disciplines; 6) develop a cohort-based program that draws upon expertise from other disciplines to build successful student teams; and 7) develop a STEM model from which other universities throughout the U.S. can learn to better serve future generations of STEM students. For example, many studies have highlighted that students who are involved in research as part of their undergraduate education achieve higher academic performance, have higher rates of retention, are more competitive for entering graduate programs, and are, ultimately, better prepared for obtaining careers in their respective disciplines [5,7,19-21]. Tinto's model of Student Retention [17,18], as well as that of his colleagues' demonstrates that engagement of students is the most critical factor in retention programs for undergraduate students $[8,9,22]$. These studies argue that if students do not feel engaged within the context of their program, they will leave the university prematurely before they earn their degrees. Engagement is defined as student-focused activities that actively link students both socially and into the classroom. Student living and learning communities and peer study groups are examples of social engagement while coenrollment in a research seminar and involvement in laboratory research are examples of academic engagement [23].

Experiential learning, as a tool, can be employed to improve STEM education by providing students with practical problem solving skills $[24,25]$. With experiential learning, the students' direct exposure and response to real world problems and reflection upon the outcomes of their actions serve as a means for the development and evolution of knowledge related to their subjects of interest [21]. Experiential learning is particularly suitable for bridging difficult subjects across multiple disciplines [26] as is 
increasingly required in the STEM disciplines. Tinto [18] has more recently emphasized the importance of faculty/mentor contact for students within a context of active student engagement through tasks that require strategies such as active and experiential learning. Thus our STEM programs embed engagement within a multi-layer approach [18], involving experiential and team centered learning, direct mentoring, leadership development, career development, academic engagement and social engagement.

Fewer than five years into each of our NSF programs, we are already observing many of the same benefits appreciated by these diversity practices in veterinary programs. These have been manifest through increased recruitment, retention, persistence, and career placements among our STEM participants. This continues to be a formative process as we collect, process, and disseminate our early findings. Over the next five years, we expect to publish our model for enhancing diversity in the STEM disciplines and we will owe much of it to the dynamic field of veterinary science and the pioneering veterinary faculty and practitioners who paved the way.

\section{Acknowledgments}

Bowser and Brown thankfully acknowledge support from the National Science Foundation (1140182), (0956059), and (1060548).

\section{References}

1. Fabio D, Brandi N, Frehill L (2008) Professional Women and Minorities: A total human resources data compendium, college student retention 17

2. Achieving an inclusive graduate community, council of graduate schools (2003) Washington, DC

3. Bowser G, Roberts N, Simmon D, Perales M (2012) The Color of Climate: Ecology, Environment, Climate Change and Women of Color-Exploring Environmental Leadership From the Perspective of Women of Color in Science. Environmental Leadership: A Reference Handbook. SAGE Publications, Inc, SAGE Publications, Inc., Thousand Oaks, CA.

4. Barlow AEL, Villarejo M (2004) Making a Difference for Minorities: Evaluation of an Educational Enrichment Program. Journal of Research in Science Teaching 41: 861-881.

5. Hathaway R, Nagda B, Gregerman S (2002) The relationship of undergraduate research participation to graduate and professional pursuit: An empirical study. J Coll Stud Dev 43: 614-631.

6. Summers MF, Hrabowski FA III (2006) Preparing minority scientists and engineers. Science 311: 1870-1871.

7. Hunter AB, Laursen SL, Seymour E (2006) Becoming a Scientist: The Role of Undergraduate Research in Students' Cognitive, Personal, and Professional Development. Science Education 91: 36-74.

8. Pascarella ET, Chapman D (1983) A multi-institutional path to analytic validation of Tinto's model of college withdrawal, American Educational Research Journal 20: 87-102.
9. Pascarella ET, Terenzini PT (1980) Predicting freshmen persistence and voluntary dropout decisions from a theoretical model. Journal of Higher Education 51.

10. Seymour E, Hewitt NM (1997) Talking about leaving: Why undergraduates leave the sciences. Westview Press, Boulder.

11. Berger JB (2001) Understanding the organizational nature of student persistence: Recommendations for practice. Journal of College Student Retention Research Theory and Practice 3: 3-22.

12. Cabrera A, Burkum K, La Nasa S (2005) Pathways to a four year degree: Detriments of transfer and degree completion. ACE/Praeger, Westport.

13. Kornegay LM (2011) A business case for diversity and inclusion: why it is important for veterinarians to embrace our changing communities. J Am Vet Med Assoc238: 1103-1105.

14. C. BVA (2012) A woman's world? Veterinary Record 171: 466-467.

15. Nolen R (2012) JAVMA News Journal of the American Veterinary Medical Association 240: 1042-1053.

16. Irvine L, Vermilya JR (2010) Gender Work in a Feminized Profession: The Case of Veterinary Medicine. Gender \& Society 24: 56-82.

17. Tinto V (1993) Leaving College: Rethinking causes and cures of student attrition, 2nd ed., University of Chicago Press, Chicago IL.

18. Tinto V (2007) Research and practice of student retention: What next. Journal of College Student Retention 8: 1-19. 
19. Boyd M, Wesemann J (2009) Broadening Participation in Undergraduate Research: Fostering Excellence and Enhancing the Impact, Council on Undergraduate Research, Washington DC.

20. Taraban R, Blanton RL (2008) Creating Effective Undergraduate Research Programs in Science - The Transformation from Student to Scientist. Teachers College Press, New York.

21. Kuh GD, Kinzie J, Schuh JH, Whitt EJ (2005) Student Success in College: Creating Conditions that Matter, Jossey-Bass, San Francisco.

22. Upcraft M, Gardner J, Barefoot D (2005) Challenge and Support: Creating Climates for First Year Student Success. Jossey-Bass, San Francisco.

23. Davis E, Bowser G, M Brown (2012) Creating the Global Leader and Global Mind-Set: Engaging Multicultural Students in Multidimensional Learning.
Environmental Leadership: A Reference Handbook. SAGE Publications, Inc, SAGE Publications, Inc., Thousand Oaks, CA.

24. Kardash C (2000) Evaluation of an undergraduate research experience: Perceptions of undergraduate interns and their faculty mentors. Journal of Educational Psychology 92: 191-201.

25. Committee on Developments in the Science of Learning with additional material from the Committee on Learning Research and Educational Practice, National Research Council (2000) How people learn: Brain, mind, experience, and school. National Academy Press, Washington, DC.

26. Itin C (1999) Reasserting the Philosophy of Experiential Education as a Vehicle for Change in the 21st Century, Journal of Experiential Education 22: 91-98. 